\title{
Determination of the amount of carbon stored in a disturbed mangrove forest in Campeche, Mexico
}

\author{
R. M. Cerón, J. G. Cerón, J. J. Guerra, J. C. Zavala, L. E. Amador, \\ E. Endañu \& G. Moreno \\ Universidad Autónoma del Carmen, Campeche, México
}

\begin{abstract}
Carbon sequestration potential of mangrove forest in Campeche, Mexico, was investigated. Field work was conducted at two sites at the border of the estuary named "Terminos Lagoon" (Estero-Pargo and Bahamitas) between February and August in 2009. The mangrove forest in both sites has been subjected to anthropogenic pollution during the last years and it can be considered as perturbed. Six sampling campaigns were performed considering three climatic periods ("Norths" season, dry season and rainy season). Seasonal influence on carbon storage was evident, but also the influence of tides was significant, with the highest carbon storage during "Norths" and dry seasons (ranged from 10.63 to $37.64 \mathrm{Kg} \mathrm{C} \mathrm{m}^{-2}$ for Estero-Pargo, and from 12.8 to $39.9 \mathrm{Kg} \mathrm{C} \mathrm{m}^{-2}$ for Bahamitas). Carbon storage was higher in flooded soils with dominant vegetation of red mangrove in comparison with sampling zones where dominant vegetation was button mangrove. Organic matter and organic carbon content were higher at $30 \mathrm{~cm}$ depth during "Norths" season, when heavy rains and long periods of tidal flooding occurred with low rates of litter export that maintained anoxic conditions. Comparing these results with carbon storage data obtained in other sites, it can be suggested that neutral and sandy soils as this study area and associations of red mangrove have a good potential of carbon sequestration. Since studied mangrove individuals were from young to mature in reproductive age, it can be conclude that this potential will increase in the next years.
\end{abstract}

Keywords: carbon sequestration potential, carbon sinks, mangrove forest, wetlands, Campeche. 


\section{Introduction}

The atmospheric concentration of carbon dioxide is currently increasing at the

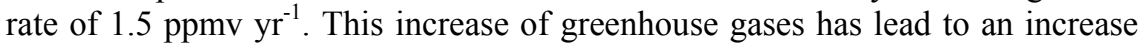
in the primitive temperature of the Earth and as a consequence to global climatic change. In spite of the strong inter-dependence between climate and soil quality [1], the role of soil organic carbon on global warming and its strategic importance as an alternative solution needs more recognition.

Wetlands are known to be important carbon sinks. Mangrove forest is characterized by a high productivity and a low ratio of sediment respiration to net primary production. For this reason, mangrove sediments have a high potential for a long term organic carbon sequestration. Furthermore, carbon storage in estuarine wetlands is an efficient process with a minimal release of greenhouse gases [2]. Although they cover only about 5\% of the earth's surface, they contain around $40 \%$ of global soil organic carbon [3]. However, it has been estimated that about $68 \%$ of the total global area of wetlands has been lost as a result of human activities, mainly due the change of the land use, converting wetlands to farmland, forestry and urban areas.

In spite of the importance of mangrove forest as a carbon sink, the most carbon storage studies are focused to terrestrial ecosystems and little attention has been given to this ecosystems. Despite in Mexico, there are 113 Ramsar sites with a total surface of wetlands of $8,161,357$ ha, and mangrove ecosystem constitutes the main wetland system, location of specific carbon sinks and their potential to sequester atmospheric carbon remains poorly defined, and there are uncertainties concerning carbon stock of wetland of local and regional scale. To complete carbon storage inventories and to reduce these uncertainties, it is necessary to obtain more information that support environmental policies to promote conservation and restoration projects as mitigation strategies. This paper reports the content of organic carbon in two sites in a disturbed mangrove forest within an important wetland in our country that has been registered as a Ramsar site [4].

\section{Methods}

\subsection{Site description}

Terminos Lagoon is located at the south western base of the Yucatan peninsula, and it is the largest estuary in Mexico. Carmen Island forms a sand barrier between Terminos Lagoon and open sea (Figure 1). Terminos Lagoon is almost completely surrounded by mangrove forest (Rhizophora mangle, Avicennia germinans, Laguncularia racemosa, and Conocarpus erectus), covering an area nearly as large as the open-water area of the lagoon itself. Therefore, mangrove forest constitutes a significant component of the lagoon ecosystem. Maximum wind speeds range from 50 to $60 \mathrm{~km} \mathrm{~h}^{-1}$, occurring during the season of winter storms named "Norths". Average annual precipitation $(1680 \mathrm{~mm})$ is seasonal with a dry season from February to May, and a wet season from June to October. 
The period where Gulf of Mexico is subjected to the influence of cold fronts, from November to February, is named "Norths" season.

Two areas were selected for this study: a forest along Estero-Pargo, a $5.3 \mathrm{~km}$ long tidal channel on the lagoon side of Carmen Island and a forest at Bahamitas located at the border of the Terminos Lagoon. Both sites are within natural protected area named “Terminos Lagoon”, ramsar site since 2004 (Figure 1).

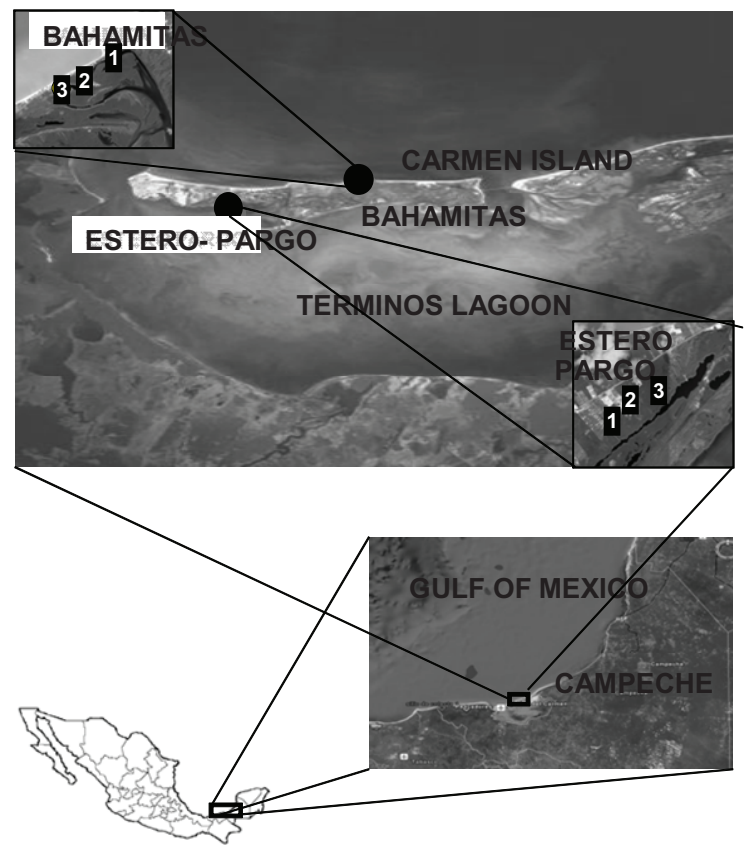

Figure 1: Location of sampling sites and sampling zones in the study area.

\subsection{Sampling method and forestry inventory}

Field work was conducted at two sites with three sampling zones for each one, between February and August 2009. In both sampling sites, mangrove forest is subject to anthropogenic exploitation and can be considered as perturbed. To assess seasonal changes on carbon storage, sampling campaigns were performed considering three climatic periods: "Norths" season, dry season and the beginning of the rainy season, with a total of six sampling campaigns. Not all sampling sites had comparable tidal influences during the study period, Bahamitas site was always flooded (received regular tidal inundation and was covered with fresh water during "Norths" and rainy seasons) whereas EsteroPargo only was flooded as a result of the occurrence of rainfall during rainy and "Norths" seasons. In each site, three sampling zones of $4 \mathrm{~m}$ x $12 \mathrm{~m}$ were selected considering free access to the zone, risks, mangrove distribution by specie and disturbances (Figure 1, Table 1). Based on visual inspections of the 
study area, transects were established in a representative area of the mangrove forest, locating three sampling points of $1 \mathrm{~m}^{2}$ approximately for each of three sampling zones for both sites.

Table 1 shows the location of these sampling zones and their general characteristics. In table 2, the forestry inventory for each sampling zone in both sites is shown.

Table 1: Location of the sampling zones and their general characteristics for both sites in the study area.

\begin{tabular}{|c|c|c|c|c|}
\hline Sampling Site & $\begin{array}{l}\text { Sampling } \\
\text { Zone }\end{array}$ & Latitude N & Longitude W & Characteristics \\
\hline \multirow{3}{*}{$\begin{array}{l}\text { ESTERO- } \\
\text { PARGO }\end{array}$} & 1 & $18^{\circ} 39^{\prime} 02.8^{\prime \prime}$ & $91^{\circ} 45^{\prime} 46.7^{\prime \prime}$ & \multirow[b]{3}{*}{$\begin{array}{l}\text { At } 20 \mathrm{~m} \text { from the } \\
\text { border of Terminos } \\
\text { Lagoon. Only } \\
\text { flooded and covered } \\
\text { by fresh water during } \\
\text { "Norths" and rainy } \\
\text { seasons. This site has } \\
\text { an association of red, } \\
\text { white and button } \\
\text { mangrove, being } \\
\text { white mangrove the } \\
\text { dominant specie. }\end{array}$} \\
\hline & 2 & $18^{\circ} 39^{\prime} 02.2^{\prime \prime}$ & $91^{\circ} 45^{\prime} 45.7^{\prime \prime}$ & \\
\hline & 3 & $18^{\circ} 39^{\prime} 02.0^{\prime \prime}$ & $91^{\circ} 45^{\prime} 45.0^{\prime \prime}$ & \\
\hline BAHAMITAS & 1 & $18^{\circ} 41^{\prime} 57.1^{\prime \prime}$ & $91^{\circ} 41^{\prime} 50.7^{\prime \prime}$ & $\begin{array}{l}\text { Presence of } \\
\text { wastewater and } \\
\text { garbage. At the } \\
\text { border of Terminos } \\
\text { Lagoon. Always } \\
\text { flooded. Flooded at } \\
\text { each tide, and } \\
\text { covered by fresh } \\
\text { water during } \\
\text { "Norths" and rainy } \\
\text { seasons. This site } \\
\text { has an association of } \\
\text { red, white and black } \\
\text { mangrove, being red } \\
\text { mangrove the } \\
\text { dominant specie. }\end{array}$ \\
\hline
\end{tabular}

Duplicate soil samples were collected from the ground to 30 and $60 \mathrm{~cm}$ depth using a $193.3 \mathrm{~cm}^{3}$ soil sampler. The corer was carefully inserted into the soil and pushed down at 0.3 and $0.6 \mathrm{~m}$. Because, of sampled soils were humid, the corer has a one-way check valve that creates a vacuum inside the corer liner as it is pushed into the soil, and when the device is pulled out of the soil it creates a suction force that retains the sample in the tube. This sampling method was used by Grossman and Reinsch [5] and by Bernal and Mitsch [6] for sampling wet soils or soils under water. 


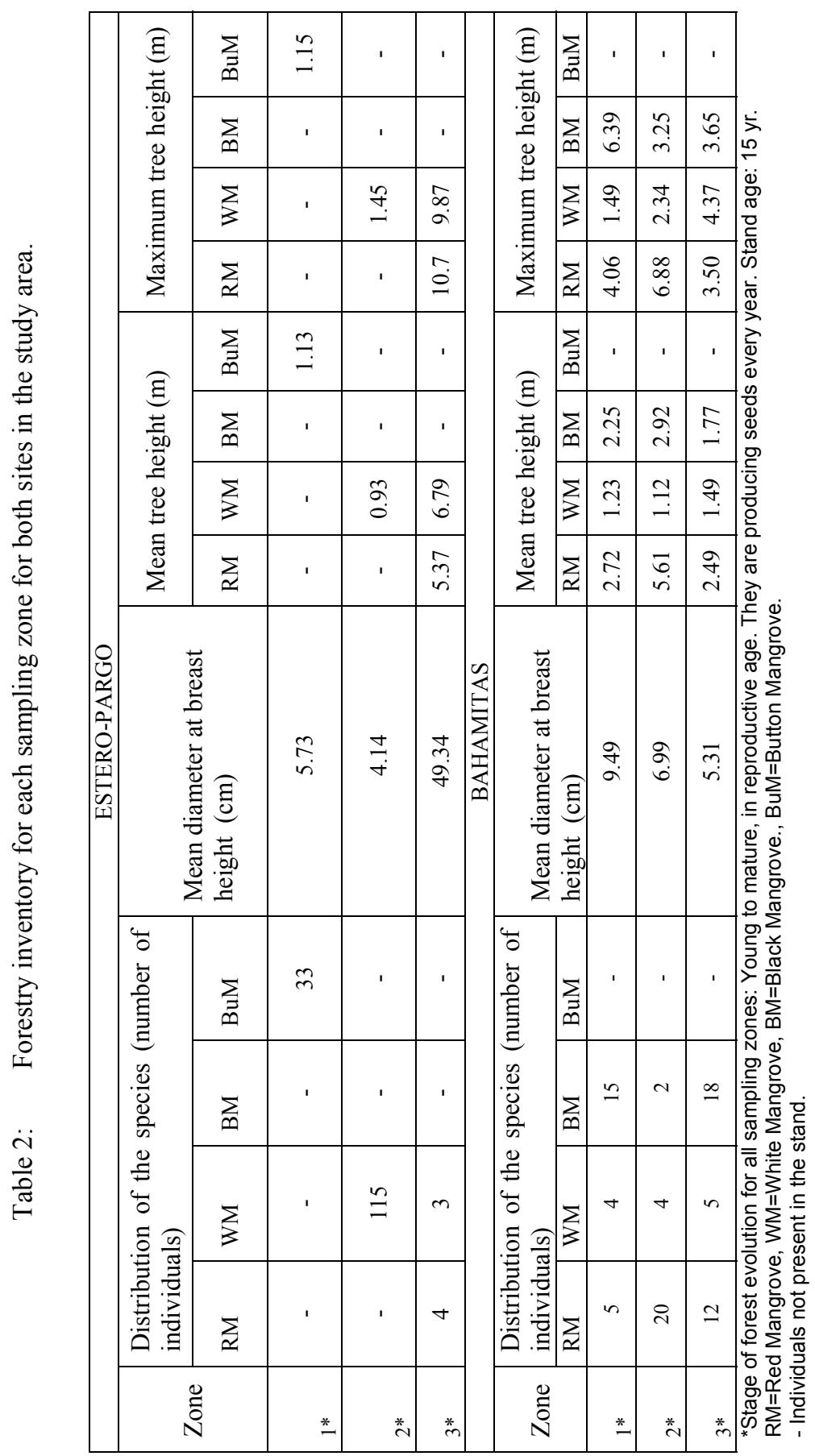


A total of 216 soil samples with replicate were taken. After extraction, each core was labelled, sealed using tight-fitting end caps, and sent for laboratory analysis [7].

\subsection{Analysis method}

For the laboratory analysis, the soil cores were removed from the tube. Free water was drained away and above-ground vegetation was removed. Wet mass was recorded and the cores then dried at ambient temperature to constant mass, this weight was registered to obtain the bulk density. Shells, rocks, roots and any living biomass were removed prior to grinding. Dry samples were ground and sieved to pass $2 \mathrm{~mm}$ particle size. Physical/Chemical parameters of each soil sample were determined according to standard procedures. $\mathrm{pH}$ and salinity were obtained using a 1:5 soil/water solution by electrical conductivity [8]. Soil mechanical composition (granulometric analysis) of each dried sample was analyzed by a hydrometer method [7]. Gravimetric humidity was determined according to Etchevers [9]. Total nitrogen was analyzed using the semi-microkjeldahl method [7]. Analysis of organic matter were made using the aciddichromate oxidation method [7], organic carbon was analyzed according to NOM-021-RECNAT [7] and bulk density according to Gandoy [10]. Forestry inventory was performed by using a clinometer (Suunto PM-5/1520).

\subsection{Estimation of carbon sequestration potential}

From organic carbon content $[\% \mathrm{CO}]$, the dry weight of soil in $\mathrm{t} \mathrm{ha}^{-1}$, the depth of sampled soil $(\mathrm{cm})$, and bulk density $\left(\mathrm{g} \mathrm{cm}^{-3}\right)$, the potential of sequestration of carbon $\left(\mathrm{Kg} \mathrm{C} \mathrm{m}^{-2}\right)$ was obtained as follows:

$$
\mathrm{MgC} \mathrm{ha}^{-1} \text { or } \mathrm{kg} \mathrm{C} \mathrm{m}{ }^{-2}=[\text { soil weight }][\% \mathrm{CO}]
$$

where:

$$
\text { Soil weight }\left[\mathrm{t} \mathrm{ha}^{-1}\right]=[\text { depth of sampled soil] [bulk density] }
$$

\subsection{Statistical analysis}

Statistical procedure involved three stages of analysis: descriptive, comparative and relational. First, summary descriptive statistics of the carbon storage were obtained for each sampling zone, sampling point, depth and season. Mean values of the chemical and physical variables were estimated as well at these scales, these mean values were compared by using Duncan test. Secondly, hypotheses tests were conducted by two-way ANOVA in order to assess for differences between sampling zones, sampling points, between depths and between climatic seasons. All tests were conducted with SAS v. 8.0 [11]. Simple linear regression was employed to relate the carbon storage registered at each sampling zone, sampling point, depth and climatic season with the chemical and physical variables measured. Pearson regression coefficients were then tested for significance $(p<0.05)$ in order to define which of the variables are significantly related with the observed values of carbon storage. 


\section{Results and discussion}

\subsection{Physical/chemical parameters}

From figure 2, it can be observed that soils were more humid during Norths and dry seasons. The influence of tides was evident in both sites.

There were statistical differences between climatic seasons and sampling depths. Humidity was not statically different in both sites and a significant correlation between humidity and storage carbon was not found. Electric conductivity ranged from 0.31 to $4.07 \mathrm{dS} \mathrm{m}^{-1}$ for Estero-Pargo, and from 2.10 to $17.38 \mathrm{dS} \mathrm{m}^{-1}$ for Bahamitas. There were statistical differences between sampling depth and climatic periods. A significant correlation between electric conductivity and storage carbon was not found.

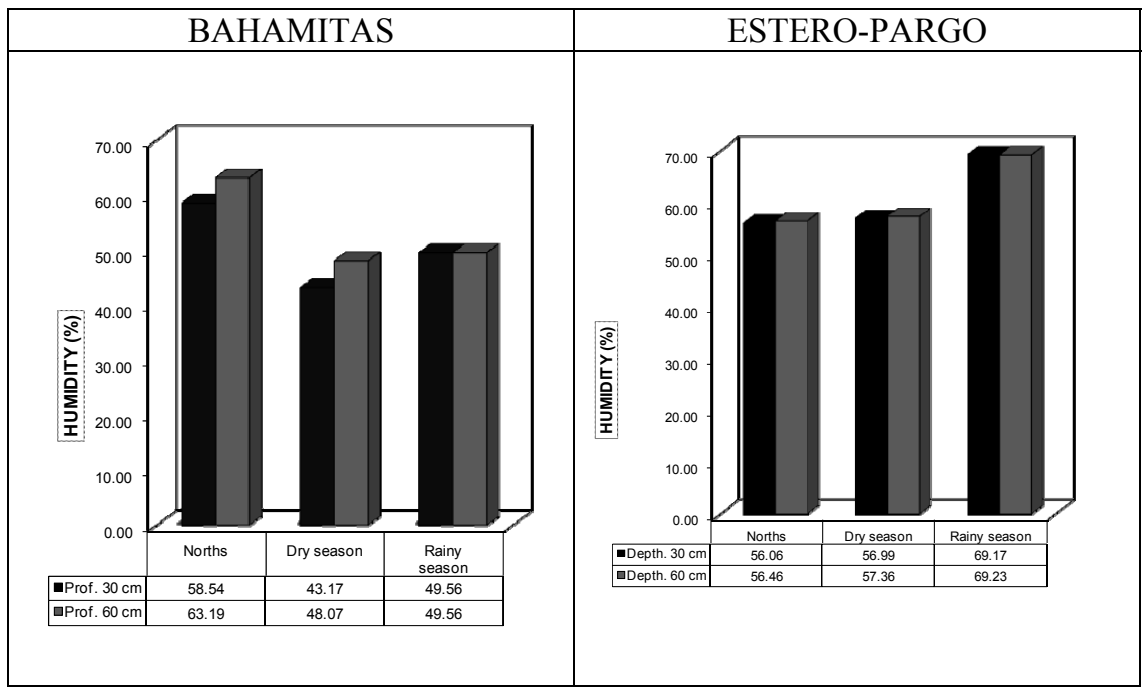

Figure 2: Gravimetric humidity for both sampling sites for each zone and for each climatic period in the study area.

Carmen Island had a sedimentary origin, for this reason, sandy soils are dominant in the study area. For both sites, soil samples showed sandy texture. In addition, $\mathrm{pH}$ values ranged from 6.89 to 7.12 for Estero-Pargo, and from 6.7 to 7.5 for Bahamitas, it suggests that neutral soils are dominant in the study area. There were not statistic differences between sampling zones and sampling depths. $\mathrm{pH}$ was not statically different in both sites and a significant correlation between $\mathrm{pH}$ and storage carbon was not found.

Bulk density ranged from 0.55 to $1.24 \mathrm{~g} \mathrm{~cm}^{-3}$ for Estero-Pargo, and from 0.57 to $1.09 \mathrm{~g} \mathrm{~cm}^{-3}$ for Bahamitas. In Estero-Pargo there were statistical differences between climatic periods and sampling depths. Bulk density was not statically different in both sites and a significant correlation between humidity and storage 
carbon was not found. On the other hand, Total nitrogen content ranged from 0.03 to $0.44 \%$ for Estero-Pargo, and from 0.02 to 0.40 for Bahamitas. There were statistical differences between climatic periods and sampling depths. Total nitrogen content was statically different in both sites considering climatic periods and a significant correlation between nitrogen content and storage carbon was not found.

\subsection{Organic matter content}

From figure 3 it can be observed that organic matter content was higher at $30 \mathrm{~cm}$ depth for all sampling zones in both sites. In study area, the long periods of tidal flooding maintained anoxic conditions (below $10 \mathrm{~cm}$ of depth) and high organic matter contents, it can explain the highest organic matter content at $30 \mathrm{~cm}$ depth. Furthermore, the accumulation process of organic matter is enhanced in sites with abundant rainfall (the heavy rains occurred during Norths season) or with a deficient drainage, it is the case of both sampling sites. During the rainy season, the accumulation of organic matter increases, however the decomposition is slow, it can explain the slightly lower values obtained for organic matter during this season, this accumulation remain until the Norths and dry seasons, resulting maximum values during these seasons.

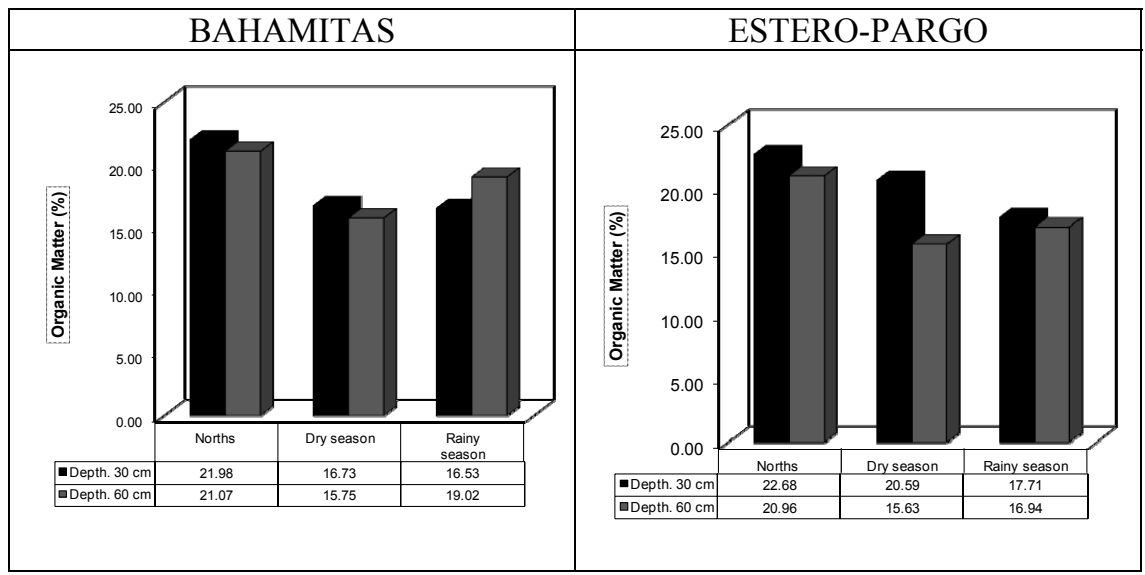

Figure 3:

Organic matter content for both sampling sites for each sampling zone and for each climatic period in the study area.

Organic carbon content ranged from 2.81 to $19.7 \%$ for Estero-Pargo, and from 4.76 to $15.73 \%$ for Bahamitas. There were statistical differences between climatic period and sampling depths. Organic carbon content was statically different in both sites related to climatic season and sampling depth. A significant correlation between organic carbon content and storage carbon was found.

The highest values were found during the Norths and dry season (Figure 4). Organic carbon content decreased slightly with increasing soil depth, this pattern 
of organic carbon distribution is a general phenomenon in forest [12]. Seasonal variation was involved, but also the influence of tides was evident. Anoxic conditions prevailing during the Norths season, when heavy rains occurred and there was a strong influence of tides (both sites were flooded all time,) may be partly responsible for the high organic carbon concentrations. During the rainy season, water sources were mixed resulting in lower organic carbon concentrations whereas during the dry season, increased evapotranspiration concentrate salts and dissolved organic carbon which are transported vertically with percolating water.

Carbon storage ranged from 10.63 to $37.64 \mathrm{Kg} \mathrm{C} \mathrm{m}^{-2}$ for Estero-Pargo and from 12.8 to $39.9 \mathrm{Kg} \mathrm{C} \mathrm{m}^{-2}$ for Bahamitas. Carbon storage was greater during the Norths and dry seasons for all sampling zones studied. Climatic variation was involved, but also, the influence of tides was evident. The degree of tidal exchange influences on the amount of organic carbon accumulated.

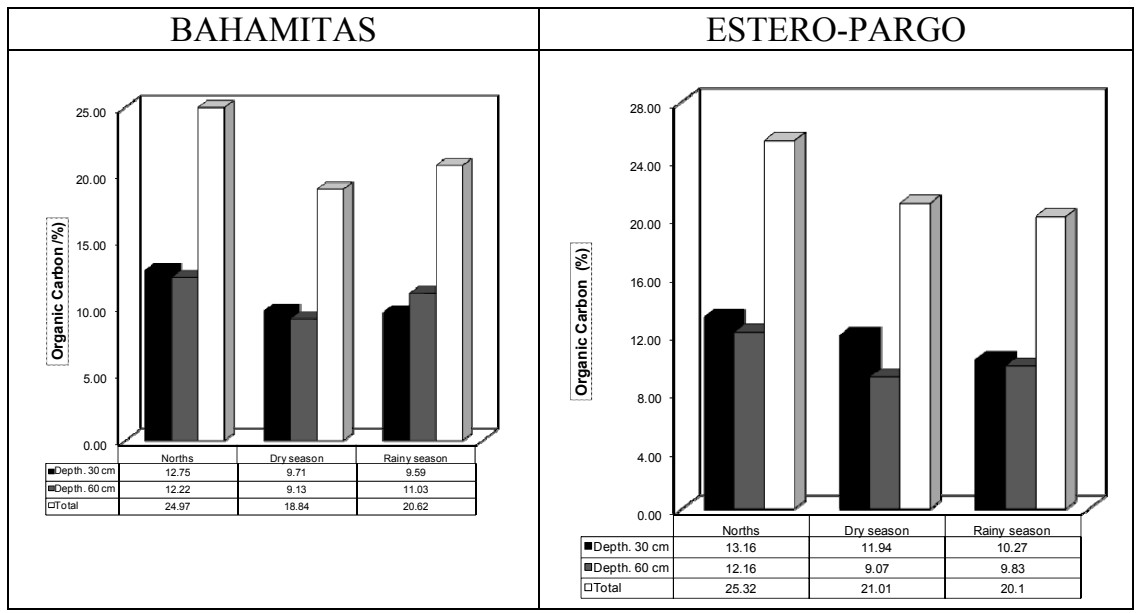

Figure 4: Organic carbon content for both sampling sites for each zone and for each climatic period in the study area.

Carbon storage is enhanced under anoxic; it can explain the highest values obtained for Norths season, when heavy rains occurred and the sites were flooded most of the time as a result of tides, because flooded wetlands provide optimal conditions for accretion of organic matter.

During the dry season, salts and dissolved organic carbon concentrates with increasing evaporation, whereas, during rainy season, pore waters were diluted with rain and run-off waters, resulting in lower dissolved organic carbon concentration, salinities and densities. In mangrove forest, the stand age is a determinant factor that influence on the amount of organic carbon in soil whatever season, Comparing our results with carbon storage data obtained in other sites (Table 3), we can suggests that sandy and neutral soils as our study area and associations of red and white mangrove have a good potential of carbon 
sequestration, considering that our mangrove individuals were from young to mature in reproductive age, we can expect that this potential will increase in the next years.

Table 3: $\quad$ Comparison of carbon storage reported by other authors.

\begin{tabular}{|c|c|c|}
\hline Site/Land Use & $\begin{array}{l}\text { Carbon storage } \\
\left(\mathrm{kg} \mathrm{C} \mathrm{m}^{-2}\right)\end{array}$ & Reference \\
\hline $\begin{array}{l}\text { Gahanna woods, Ohio, USA. Isolated } \\
\text { and forested wetland. }\end{array}$ & 3.03 & [6] \\
\hline $\begin{array}{l}\text { Old Woman Creek, Ohio, USA. } \\
\text { Riverine flow-through wetland. }\end{array}$ & 2.77 & [6] \\
\hline $\begin{array}{l}\text { La Selva, Costa Rica. Isolated and } \\
\text { forested wetland. }\end{array}$ & 0.43 & [6] \\
\hline $\begin{array}{l}\text { Earth University, Costa Rica. Slow- } \\
\text { flowing slough wetland. }\end{array}$ & 1.67 & [6] \\
\hline $\begin{array}{l}\text { Palo Verde, Costa Rica. Riverine } \\
\text { Flow-through wetland. }\end{array}$ & 1.36 & [6] \\
\hline $\begin{array}{l}\text { Southern California, USA. Coastal } \\
\text { lagoon and wetland complex. }\end{array}$ & 0.033 & [13] \\
\hline $\begin{array}{l}\text { Okinawa Island, Japan. Pioneer } \\
\text { Mangrove Stand. }\end{array}$ & 5.73 & [12] \\
\hline $\begin{array}{l}\text { Tabasco, Mexico. Red and white } \\
\text { mangrove stand. }\end{array}$ & $47.2-82.2$ & [14] \\
\hline $\begin{array}{l}\text { Southeast Australia } \\
\text { Disturbed Wetland soils }\end{array}$ & 6.61 & [15] \\
\hline $\begin{array}{l}\text { Southeast Australia } \\
\text { Undisturbed Wetland soils }\end{array}$ & 11.19 & [15] \\
\hline $\begin{array}{l}\text { Sydney, Australia } \\
\text { Coastal wetlands }\end{array}$ & 13.9 & [16] \\
\hline $\begin{array}{l}\text { Tropical and subtropical China } \\
\text { Marsh vegetation }\end{array}$ & 40.0 & [17] \\
\hline $\begin{array}{l}\text { Brazil, } \\
\text { oxysol }\end{array}$ & $12.0-24.0$ & [18] \\
\hline $\begin{array}{l}\text { Brazil, } \\
\text { Agricultural soils }\end{array}$ & $2.0-10.0$ & [19] \\
\hline $\begin{array}{l}\text { Campeche, Mexico. Neutral and sandy } \\
\text { soils, Perturbed Mangrove forest. } \\
\text { Bahamitas. }\end{array}$ & 23.16 & This study \\
\hline $\begin{array}{l}\text { Campeche, Mexico. Neutral and sandy } \\
\text { soils, Perturbed Mangrove forest. } \\
\text { Estero-Pargo. }\end{array}$ & 23.08 & This study \\
\hline
\end{tabular}




\section{Conclusions}

During this research, study area was subjected to severe cold fronts associated with intense rains, and the influence of tides in both sites was significant. Organic matter and organic carbon content decreased slightly with increasing soil depth. Carbon storage was highest during Norths and Dry seasons. In both sites, Estero-Pargo and Bahamitas were under the influence of tides and heavy rains, and were flooded the most of time. The anoxic conditions prevailed in both sites favoured the accumulation of organic matter and organic carbon in the sampled soils. In addition, accumulation of organic matter and carbon storage were also higher during the dry season, it is expected since during this season, enhanced evapotranspiration process concentrate and increase the salts and dissolved organic carbon. In the other hand, storage carbon was slightly lower during the rainy season, when pore waters were diluted with rain and run-off waters, resulting in lower dissolved organic carbon concentration, salinities and densities. Sampling zones where button mangrove is a dominant specie showed a lower carbon storage, whereas, sampling zones flooded the most of the time, with associations of red mangrove-black mangrove and red mangrove-white mangrove showed the highest carbon storage.

\section{References}

[1] Jenny, H. 1980. The soil Resource: Origin and Behavior. Springer, New York. 377 pp.

[2] Magenheimer, J.F., Moore, T.R., Chmura, G.L., Daoust, R.J., 1996. Methane and carbon dioxide flux from a macrotidal salt marsh, Bay of Fundy, New Brunswick. Estuaries 19, 139-145.

[3] Mitsch, W.J., Gosselink, J.G. 2000. Wetlands. John Wiley \& Sons Inc. New York. 920 pp.

[4] Ramsar, 1999. Annotated Ramsar list of wetlands of international importance. Resolution VII.11. Conference of the contracting parties. May 1999. Bucharest, Romania.

[5] Grossman, R.B., Reinsch, T.G., 2002. The solid phase: bulk density and linear extensibility. In: Methods of soil analysis, Part 4-Physical methods. Soil Science Society of America. Madison, Wisconsin. 201-228.

[6] Bernal, B., Mitsch, W.J., 2008. A comparison of soil carbon pools and profiles in wetlands in Costa Rica and Ohio. Ecological Engineering 34, 311-323.

[7] NOM-021-RECNAT-2000. Diario Oficial, 31 de diciembre de 2002.

[8] Van Reeuwijk, L.P., 2002. Procedures for soil analysis. International Soil Reference and Information Centre and Food and Agriculture Organization of the United Nations. $6^{\text {th }}$. Technical Paper 9.

[9] Etchevers, R.J.D., Monreal, M.C., Hidalgo, M.C., Acosta, M.M., Padilla, C.J., López, R.R.M., 2005. Manual para la determinación de carbono orgánico en la parte aérea y subterránea de sistemas de producción de ladera. Colegio de Postgraduados. México. 
[10] Gandoy, B.W. 1992. Manual de laboratorio para el manejo físico de suelos. Universidad Autónoma Chapingo. Departamento de Suelos. Chapingo, México.

[11] Rebolledo, H. 2002. Manual SAS por computadora. Análisis estadístico de datos experimentales. Editorial Trillas. México, D.F.

[12] Khan, M.N.I., Suwa, R., Hagihara, A., 2007. Carbon and nitrogen pools in a mangrove stand of Kandelia obovata (S., L.) Yong: Vertical distribution in the soil-vegetation systems. Wetlands. Ecol. Manage 15, 141-153.

[13] Brevik, E., Homburg, J., 2004. A 500 year record of carbon sequestration from a coastal lagoon and wetland complex, Southern California, USA., Catena 57, 221-232.

[14] Moreno, E., Guerrero, A., Gutiérrez, M., Ortíz, C., Palma, J., 2002. Los Manglares de Tabasco, una reserva natural de carbono. Madera y Bosques. Número especial. 115-128.

[15] Howe, A.J., Rodríguez, J.F., and Saco, P. M., 2009. Surface evolution and carbon sequestration in disturbed and undisturbed wetland soils of the Hunter estuary, southeast Australia. Estuarine, coastal and shelf science. 84, 75-86.

[16] Webb, A., 2002. Pre-clearing Soil Carbon Levels in Australia. National Carbon Accounting System Technical Report No. 12. Australian Greenhouse Office, Canberra, 204 p.

[17] Zhong, L., and Qiguo, Z., 2001. Organic carbon content and distribution in soils under different land uses in tropical and subtropical China. Plant and Soil 231,175-185.

[18] Lal, R., 2001. World cropland soils as a source or sink for atmospheric carbon. Advances in Agronomy 71, 145-191.

[19] Rabenhorst, M.C., Swanson, D., 2000. Classification of soils: Histosols. E183:E-208 p. In: Sumner M.E., ed. Handbook of soil science. CRC Press. Nueva York, EUA. 